\title{
Sero-prevalence of sheep brucellosis in three different locations in Kassala state: a short communication
}

\begin{abstract}
A cross-sectional study was conducted from April to December 2011 to determine the sero-prevalence of brucellosis in sheep in Kassala state, Eastern Sudan. A total number of 503 serum samples were collected from sheep that were conveniently and/ or randomly selected. All collected samples were screened using modified rose Bengal plate test (mRBPT). Moreover, mRBPT positive samples were subjected to competitive enzyme-linked immunosorbent assay (cELISA). The estimated overall sero-prevalence was found to be $9.3 \%(43 / 503,95 \%$ CI from 6.80 to 11.9$)$. Additionally, Al-Girba locality and Garrage sheep were showing higher sero-prevalences than other localities and sheep breeds. The univariate and multivariate analyses revealed that location and breed were statistically related with RBPT-seropositive status. It can be concluded that brucellosis is prevalent in sheep in the investigated locations in Kassala. Studies investigating potential risk factors that enhance spreading of brucellosis in sheep are warranted.
\end{abstract}

Keywords: Sero-prevalence, sheep, brucellosis, RBPT, Eastern Sudan
Volume 7 Issue 2 - 2018

\author{
Yassir Adam Shuaib,' Mohamed Elsadig \\ Mansour, ${ }^{2}$ Hatim Hamad Ibrahaem, ${ }^{2}$ Saad \\ El-Tiab Mohamed-Noor,' Mohammed Ishag \\ Boukhari,' Makarim Habeeb Issa, ${ }^{2}$ Enaam \\ Mohamed El-Sanousi,' Siham Elyas Suliman,' \\ Abdelhamid Ahmed Mohamed El-Fadil, \\ Mohamed Abdelsalam Abdalla' \\ 'College of Veterinary Medicine, Sudan University of Science and \\ Technology, Sudan \\ ${ }^{2}$ Veterinary Research Institute, Sudan
}

Correspondence: Yassir Adam Shuaib, College of Veterinary Medicine, Sudan University of Science and Technology, P.O. Box 204 (Hilat Kuku), Khartoum North, Sudan, Tel +2499|296296I, Email vet.aboamar@gmail.com

Received: February 19, 2018 | Published: April 03, 2018

\section{Introduction}

Brucellosis is one of the most important infectious bacterial diseases of animals and humans. ${ }^{1,2}$ It is caused by members of the genus Brucella, including Brucella melitensis, B. abortus, B. suis, $B$. neotamae, $B$. ovis and $B$. canis. ${ }^{1}$ The natural reservoirs of $B$. melitensis and $B$. ovis are sheep and goats. Humans are susceptible to infections caused by B. melitensis, B. suis, B. abortus and B. canis. ${ }^{1}$ The significance of the disease is explained by its zoonotic dimension and the economic impact. ${ }^{1,2}$ Many important factors contribute to the prevalence and spreading of brucellosis in animals, including farming system and management practices, farm sanitation, livestock movement, mixing and trading of animals, and sharing of grazing grounds. ${ }^{3}$ Almost invariably, the disease is transmitted by direct or indirect contact with infected animals or their products..$^{1-3}$ In general, symptoms of brucellosis are abortion, reduced milk production, reduced fertility and weak offspring. In addition, hygromas, orchitis, and spondylitis are other specific manifestations that are frequently diagnosed in cattle, sheep, and swine., ${ }^{1,2}$ High rates of brucellosis infection in sheep usually cause great incidences of infection in other animals and humans. ${ }^{2-4}$ In many African countries, the prevalence of brucellosis among animals is not very well investigated or even unknown in some areas. In addition, because of limited resources in these countries, control of brucellosis has been very difficult and lagged far behind. ${ }^{4}$ Sero-prevalence of brucellosis in sheep in Kassala is not very well studied. Only few countable surveys were carried out in the state. ${ }^{5,6}$ Therefore, this survey is aiming at determining the seroprevalence of brucellosis in sheep in Kassala state.

\section{Materials and methods}

\section{Study area}

Kassala state is located between latitude $14^{\circ} \mathrm{N}$ and $17^{\circ} \mathrm{N}$ and longitude $34^{\circ} \mathrm{E}$ and $37^{\circ} \mathrm{E}$ in the eastern part of the Sudan. In the east, it is bordered by Eritrea and in the north it is bordered by the Red Sea state, in the west by Khartoum and the River Nile states and by Al-Gadarif state in the southwest. Annual rainfall is from June to September with a very hot summer and cold winter. During rainfall season, Kassala state is rich in fodder and water. Mixed crop-livestock, nomadic, and semi-nomadic production systems predominate in the state. Animals are raised and produced in Kassala for domestic consumption and for export to international markets. The state's estimated livestock population is around 4.5 million heads. ${ }^{7}$

\section{Study design and sampling strategy}

A cross-sectional study was conducted from April to December 2011 using a multistage sampling strategy. ${ }^{8}$ Three localities of the 11 localities of Kassala state were conveniently and/or randomly selected. These were Wad Al-Hilaiwo, West Kassala, and Al-Girba. Within each of the selected localities, peasant associations or villages, sheep flocks and individual animals were randomly and/or conveniently sampled. ${ }^{8}$

\section{Sample size}

The following standard formula: $\mathrm{n}=(1.96)^{2} \times \mathrm{P}_{\text {exp }} \times(1-\mathrm{Pexp}) / \mathrm{d}^{2}$ was used to calculate the sample size (n) for determining the prevalence of anti-brucella antibodies in sheep. ${ }^{8}$ Where: $\mathrm{n}$ is the required sample size, $\mathrm{P}_{\text {exp }}$ is the expected prevalence, and $\mathrm{d}$ is the desired absolute precision $( \pm 5 \%)$. Considering all parameters of the formula, $\mathrm{n}$ was determined to be 503 animals.

\section{Serum samples}

Whole blood samples were taken from selected animals as recommended by OIE. ${ }^{9}$ About $3 \mathrm{ml}$ of blood were taken from the jugular veins using plain vacutainer tubes. After that, the tubes were kept in a slant position and protected from direct sunlight until 
the blood was clotted and thereafter the serum was separated. The separated serum was transferred to sterile cryovials and kept at $-20^{\circ} \mathrm{C}$ until processed.

\section{Laboratory tests}

Modified rose bengal plate test (mRBPT): The test samples and antigen were removed from the refrigerator and left at room temperature for at least 30 minutes before the test was performed. All samples were screened using $\mathrm{mRBPT}$ according to the procedures described by OIE. ${ }^{9}$ Briefly, $60 \mu 1$ of serum were dispensed onto the plate and $30 \mu \mathrm{l}$ of the antigen were dropped alongside the serum. Using applicator stick, the antigen and the serum were mixed and examined for agglutination after 4 minutes of gentle shacking. Any visible agglutination was considered as positive result. Absence of agglutination indicated that the sample was negative.

Competitive enzyme-linked immunosorbent assay (cELISA): The competitive enzyme-linked immunosorbent assay (cELISA) kit was obtained from the Central Veterinary Laboratory, Weybridge, UK. The test was conducted according to the instructions of the manufacturer. Initially, the diluting buffer, wash solution, stopping solution, conjugate solution, and controls were reconstituted. Test serum samples were added per each well of the microtiter plate which has sixty columns (wells). A volume of $100 \mu \mathrm{l}$ of the prepared conjugate solution was then dispensed in all wells. It was then shaken for 2 minutes in order to mix the serum with the conjugate solution. The plate was then covered with a lid and incubated at room temperature for 3 minutes. The content of the plate was after that discarded and rinsed 5 times with washing solutions, and then dried. Thereafter, 100 $\mu \mathrm{l}$ of the substrate chromogen solution were added to all wells. The plate was kept at room temperature for 10 minutes. The reaction was slowed by adding $100 \mu \mathrm{l}$ of the stopping solution to each well. To set up the controls, $20 \mathrm{ml}$ of the negative control were added to wells A11, $\mathrm{A} 12, \mathrm{~B} 11, \mathrm{~B} 12, \mathrm{C} 11$, and $\mathrm{C} 12$, while another $20 \mathrm{ml}$ of the positive controls were added to wells F11, F12, G11, G12, H11, and well H12. Wells D11, D12, E11, and E12 served as conjugated controls. The results of the tested samples wells were interpreted by comparing to the control wells as follows: very weak or no color development in the well indicated negative result while a strong color development in wells indicates positive result.

Table I Estimated sero-prevalences of brucellosis in sheep in Kassala state (April - December 20I I)

\begin{tabular}{lllll}
\hline Risk Factors & No. tested & No. positive & $\%$ & $\begin{array}{l}95 \% \mathbf{C l} \\
\text { Lower - Upper }\end{array}$ \\
\hline $\begin{array}{llll}\text { Localities } \\
\text { Wad Al-Hilaiwo }\end{array}$ & 190 & 12 & $6.30^{\mathrm{a}}$ & $3.30-10.8$ \\
West Kassala & 164 & 6 & $3.70^{\mathrm{a}}$ & $1.40-6.60$ \\
Al-Girba & 159 & 29 & $18.2^{\mathrm{b}}$ & $12.2-24.2$ \\
Breeds & & & & \\
Dubassy & 237 & 13 & $5.50^{\mathrm{a}}$ & $2.60-8.40$ \\
Gaash & 64 & 2 & $3.10^{\mathrm{a}}$ & $0.40-7.40$ \\
Garrage & 121 & 32 & $26.4^{\mathrm{b}}$ & $18.6-34.3$ \\
Age group (yrs) & & & & \\
$\leq 1$ & 133 & 10 & $7.50^{\mathrm{a}}$ & $3.00-12.0$ \\
$>1-2$ & 79 & 7 & $8.90^{\mathrm{a}}$ & $2.60-15.1$ \\
\hline
\end{tabular}

Citation: Shuaib YA, Mansour ME, Ibrahaem HH, et al. Sero-prevalence of sheep brucellosis in three different locations in Kassala state: a short communication. J Dairy Vet Anim Res. 2018;7(2):53-57. DOI: 10.15406/jdvar.2018.07.00189
The Statistical Package for Social Sciences (SPSS) for Windows ${ }^{\circledR}$ version 22.0 (SPSS Inc., Chicago, Illinois) was used to calculate frequencies and prevalence by cross-tabbing. Furthermore, univariate and multivariate analyses were also performed.

\section{Results}

A percentage of $9.3(n=47,95 \%$ CI $6.80-11.9)$ of the RBPTscreened sheep serum samples were positive reactors, of which the cELISA confirmed the positivity of $55.3 \%(26 / 47)$. Significant statistical variations in sero-prevalences of brucellosis in sheep were observed between localities and breeds but not between males and females and among different age groups (Table 1). Al-Girba locality (18.2, 95\% CI from 12.2 to 24.2$)$ and Garrage sheep (26.4, 95\% CI from 18.6 to 34.3 ) were showing statistically higher seroprevalences of brucella than Wad Al-Hilaiwo and West Kassala localities and Dubassy and Gaash sheep respectively (Table 1). Among the different investigated age groups, proportions of sero-positive animals ranged from $7.5 \%(95 \%$ CI between 3.00 and 12.0$)$ to $10.1 \%$ (95\% CI between 6.10 and 14.1), while proportions of male and female RBPT-positive reactors were $9.6 \%$ (95\% CI from 4.60 to 14.5$)$ and $9.0 \%$ (95\% CI from 6.10 to 11.9 ) correspondently. Different proportions of seropositive samples were observed among the investigated categories of the individual animal risk factors. Geographical location $\left(\chi^{2}=23.56\right.$, $\mathrm{df}=2, \mathrm{p}$-value $=0.001)$ and breed $\left(\chi^{2}=15.61, \mathrm{df}=2, \mathrm{p}\right.$-value $\left.=0.001\right)$ were statistically associated with the seropositive status of RBPT at p-value of $\leq 0.05$ in the univariate analysis (Table 2). Nevertheless, age group and sex were not associated with RBPT positivity.

Logistic regression analysis was carried to assess the combined relationship between geographical location and breed. "The regression coefficients $(\operatorname{Exp}(\mathrm{B}))$ express 'odds ratios' $(\mathrm{OR})(=$ the increased or decreased probability $(\mathrm{OR} \neq 1))$ of sero-positivity occurrence in comparison to the reference $(\mathrm{OR}=1)$ ". ${ }^{10}$ Al-Girba locality $(\mathrm{OR}=6.24$, $95 \%$ CI from 1.45 to 27.6 , $\mathrm{p}$-value $=0.015$ ) and Garrage sheep $(\mathrm{OR}=7.77,95 \% \mathrm{CI}$ between 1.02 and 57.6, p-value $=0.047)$ were significantly associated with increased odds of being RBPT positive (Table 3).

\section{Data Management and Analysis}




\begin{tabular}{lllll} 
Table Continued.... & No. tested & No. positive & $\%$ & $\begin{array}{l}\mathbf{9 5 \%} \mathbf{C l} \\
\text { Lower }- \text { Upper }\end{array}$ \\
\hline$>2-3$ & 83 & 8 & $9.60^{\mathrm{a}}$ & $3.30-16.0$ \\
$>3$ & 218 & 22 & $10.1^{\mathrm{a}}$ & $6.10-14.1$ \\
Sex & & & & \\
Male & 136 & 13 & $9.60^{\mathrm{a}}$ & $4.60-14.5$ \\
Female & 377 & 34 & $9.00^{\mathrm{a}}$ & $6.10-11.9$ \\
Total & 503 & 47 & 9.3 & $6.80-11.9$ \\
\hline
\end{tabular}

Different superscripts indicate significant difference.

No, number; $\mathrm{Cl}$, confidence interval; and yrs, years

Table 2 Univariate association between brucellosis positivity and potential risk factors in sheep in Kassala state (April - December 20II)

\begin{tabular}{llllll}
\hline Risk Factors & No. tested & $\%$ & df & X2 & p-value \\
\hline Localities & & & 2 & 23.56 & 0.001 \\
Wad Al-Hilaiwo & 190 & 6.3 & & & \\
West Kassala & 164 & 3.7 & & & \\
Al-Girba & 159 & 18.2 & & & \\
Breeds & & & 2 & 15.61 & 0.001 \\
Dubassy & 237 & 5.5 & & & \\
Gaash & 64 & 3.1 & & & \\
Garrage & 121 & 15.1 & & & \\
Age group (yrs) & & & 3 & 0.689 & 0.395 \\
$\leq 1$ & 133 & 7.5 & & & \\
$>$ I - 2 & 79 & 8.9 & & & \\
$>2-3$ & 83 & 9.6 & & & \\
$>3$ & 218 & 10.1 & & & \\
Sex & & & 1 & 0.48 & \\
Male & 136 & 9.6 & & \\
Female & 377 & 9 & & \\
\hline
\end{tabular}

No, number; df, degree of freedom; and yrs, years

Table 3 Multivariate association of potential risk factors with brucellosis positive status in sheep in Kassala state (April - December 20I I)

\begin{tabular}{lllllll}
\hline Risk factors & No. tested & No.positive & $\%$ & Exp(B) & $\begin{array}{l}95 \% \mathbf{C l} \\
\text { Lower - Upper }\end{array}$ & p-value \\
\hline Localities & & & & & & \\
West Kassala & 164 & 6 & 3.7 & ref & & 0.23 \\
Wad Al-Hilaiwo & 190 & 12 & 6.3 & 2 & $0.70-5.07$ & 0.001 \\
Al-Girba & 159 & 29 & 18.2 & 6.03 & $2.32-13.7$ & \\
Breeds & & & & & & 0.447 \\
Gaash & 64 & 2 & 3.1 & ref & & 0.022 \\
Dubassy & 237 & 13 & 5.5 & 1.8 & $0.40-8.19$ & $1.28-23.7$ \\
Garrage & 121 & 32 & 15.1 & 5.51 & &
\end{tabular}

No, number; $\operatorname{Exp}(B)$, regression coefficients; and ref, $\operatorname{Exp}(B)$ equals I 


\section{Discussion}

This survey was carried out to determine the sero-prevalence of brucellosis in sheep in Kassala state. A proportion of 9.3\% of the investigated samples were RBPT-positive reactors. In addition, significant variations in seroprevalences of brucellosis were observed amongst the investigated geographical locations and sheep breeds. The univariate and multivariate analyses revealed statistical association between location and breed with RBPT-seropositive status. Brucellosis in sheep is basically caused by B. melitensis and $B$. ovis. However, other brucella species can also be significant etiological agents of brucellosis in sheep. ${ }^{1,6,11,12}$ This disease has a wide geographical distribution. ${ }^{1,13}$ It has been reported in most subSaharan African countries including the Sudan..$^{1,5,13-15}$ It has a very high incidence in many countries. ${ }^{11}$ Its importance is due to its public health impact as one of the important zoonoses that are transmissible to humans. Besides, brucellosis in sheep results in huge economic losses to the animal production sector which might reach US \$2 million per year in some parts of the world. ${ }^{11,16}$ The overall sero-prevalence of antibodies against brucellosis in sheep in the present study is higher than the sero-prevalences reported previously in the Sudan that ranged from $0.7 \%$ to $3.4 \% ., 5,14,17,18$ In similar settings in other areas across the world, sero-prevalences were considerably diverse and were between $0.0 \%$ and $29.3 \% .^{12,19-24}$ This heterogeneity of results could possibly be related to differences in the tested number of samples and to differences in the practiced animal production systems in each area. Comparisons of sero-prevalences showed that Al-Girba locality and Garrage sheep had higher proportions of RBPT-positive reactors than other localities and breeds, confirming the findings of Yesuf et al. ${ }^{25}$ who observed a positive association of sheep brucellosis with geographical locations, breed, age and sex. Moreover, Radostits et al. ${ }^{1}$ indicated that proportions of brucella test-negative and testpositive animals could probably be influenced by age, sex, breed and reproductive status of individual animals. However, Abdallah et al. ${ }^{14}$ and Khuzaima et al. ${ }^{15}$ did not observe variations between the seroprevalences of the categories of risk factors of brucellosis in small ruminants in the Sudan. Variations of sero-prevalences between locations could probably be explained by animal husbandry and methods adopted in animal production, while discrepancies of seroprevalences between breeds could be related to natural resistance. ${ }^{1}$

In general, the findings of this survey demonstrates that brucellosis is prevalent in sheep in Kassala. Because brucella infection in sheep leads to the appearance of the disease in other animals and humans, disregarding the current finding may represent a potential hazard for both animals and human in the study area. Moreover, the current finding highlights the need of screening of animals that are bought for breeding. Veterinarians who deal with sheep in animal clinics and hospitals could likely be at risk of becoming infected with brucellosis. Thus, taking protective measures, particularly when treating cases of abortions, using antiseptics and gloves is a pre-request in such instances as it would reduce the risk of contracting brucellosis during the intervention. Sheep owners and herders could be infected with brucellosis by consuming milk and meat that are not very well heated and cooked. Investigating different geographical locations in Kassala is one of the strengths of the present study. Additionally, it is the use of RBPT for screening of the collected samples and cELISA for confirming the positive results of the screening test. Nevertheless, failure to investigate management risk factors is a limitation

\section{Conclusion}

In summary, brucellosis is prevalent in sheep in Kassala. Geographical location and breed are factors that increase the risk of sero-positivity. Studies investigating potential risk factors that enhance spreading and transmission of brucellosis in sheep are warranted as well as the socio-economic impact of brucellosis in sheep should be understood.

\section{Acknowledgement}

None

\section{Conflict of interest}

None.

\section{References}

1. Radostits OM, Gay CC, Blood DC, et al. Disease caused by Brucella spp. A Textbook of the Disease of Cattle, Sheep, Pigs, Goats and Horses. 10th ed. ELBS Bailliere Tindall: London; 2007. P. 870-871.

2. Acha PN, Szyfres B. Bacterioses and mycoses: in zoonoses and communicable disease common to man and animals. $3^{\text {rd }}$ Ed. volume 1 (Scientific and Technical Publication No.: 580). PAHO Cataloguing-inPublication: Washington DC; 2001. p. 40-67.

3. Kabagambe EK, Elzer PH, Geaghan JP, et al. Risk factors for Brucella seropositivity in goat herds in eastern and western Uganda. Prev Vet Med. 2001;52(2):91-108.

4. McDermott JJ, Arimi SM. Brucellosis in sub- Saharan Africa: epidemiology, control and impact. Vet Microbiol. 2001;90(1):111-134.

5. Omer MM, Abdelaziz AA, Abusalab SMA, et al. Survey of brucellosis among sheep, goat, camels and cattle in kassala area, Eastern Sudan. $J$ Anim Vet Adv. 2007;6(5):635-637.

6. Gumaa MM, HM Osman, MM Omer, et al. Seroprevalence of brucellosis in sheep and isolation of Brucella abortus biovar 6 in Kassala State, Eastern Sudan. Rev sci tech Off int Epiz. 2014;33(3):957-965.

7. MARF. Department of Statistic and Information. Annual Report. Ministry of Animal Resources and Fisheries, Khartoum, the Sudan. 2009.

8. Thrusfield M. Veterinary Epidemiology. 3rd ed. Black Well Science 1td: United Kingdom; 2007. p. 220-221.

9. OIE. Bovine brucellosis.Terrestrial Manual Chapter 2.4.3. World Organization for Animal Health (OIE): Paris; 2009.

10. Shuaib YA. Peste des petits ruminants in sheep in the Sudan: a study on sero-prevalence and risk factors. Master Thesis: Ethiopia; 2011.

11. Dubie T, M Adugna, T Sisay. et al. The economic and public health significance of brucellosis. Global Research Journal of Public Health and Epidemiology. 2014;1(7):54-64.

12. Yohannes M, H Degefu, T Tolosa, et al. Brucellosis in Ethiopia: a review. African Journal of Microbiology Research. 2013;7(14):1150-1157.

13. Ducrotoya M, WJ Bertub, G Matopec, et al. Brucellosis in Sub-Saharan Africa: Current challenges formanagement, diagnosis and control. Acta Tropica. 2017;165: 179-193.

14. Abdallah AA, AM Elfadil, EM Elsanousi, et al. Seroprevalence and Risk Factors of Brucellosis in Sheep in North Kordofan State, Sudan. IOSRJAVS. 2015;8(1):31-39.

15. Khuzaima BA, Hatim HI, YA Shuaib, et al. Sero-prevalence of anti- 
brucella antibodies in goats in El-Gedarif state, Eastern Sudan. ARC Journal of Animal and Veterinary Sciences. 2018;4(1):1-8.

16. McDermott J, D Grace, J Zinsstag. Economics of brucellosis impact and control in low-income countries. Rev sci tech Off int Epiz. 2013;32(1):249-261

17. Osman M A, AE Abdelgadir. Detection of Brucellosis in sheep intended for export and local slaughter in Khartoum State, Sudan. African Journal of Microbiology Research. 2012;6(39):6805-6810.

18. Solafa ZE, TE Angara, AA Elfadil, et al. Prevalence and Risk Factors of Ruminants Brucellosis in Jabel Aolia Locality, Sudan. Sudan Journal of Science and Technology. 2014;15(2):60-72.

19. Cadmus SIB, Ijagbone IF, Oputa HE, et al. Serological survey of Brucellosis in livestock animals and worker in Ibadan, Nigeria. African Journal of Biomedical Research. 2006;9:163-168.

20. Abdel Hafez SM, Abd El Razik KA, Hassan HM et al. Comparative diagnosis of ovine brucellosis using single step blood-PCR with old and new serological tools. African Journal of Microbiology Research 2001;5(23):3976-3980.
21. Bertu WJ, Ajogi I, Bale JOO, et al. Sero- epidemiology of brucellosis in small ruminants in plateau state, Nigeria. African Journal of Microbiology Research. 2010;4(19):1935-1938.

22. Ferede Y, Mengesha D, Mekenen G. et al. A study on the seroprevalence of small ruminant brucellosis in and around Bahir Dar, North West Ethiopia. Ethiop Vet J. 2011;15(2):35-44.

23. Hegazy YM, Moawad A, Osman S, et al. Ruminant Brucellosis in the Kafr El Sheikh Governorate of the Nile Delta, Egypt: Prevalence of Neglected zoonosis, PLoS Negl Trop Dis. 2011;5(1):944.

24. Rahman MS, Her M, Kim J, et al. Brucellosis among ruminants in some districts of Bangladesh using four conventional serological assays. African Journal of Microbiology Research. 2012;6(22):4775-4781.

25. Yesuf M, Alemu S, Temesgen W, et al. Seroprevalence of ovine Brucellosis in South Wollo, North Eastern Ethiopia. East Afr J Public Health. 2011;9(3):288-291. 